Once the patient's cardiac state has been stabilised gastric lavage should be undertaken and calcium polystyrene sulphonate-for example, Calcium Resonium $60 \mathrm{~g}$-left in the stomach to reduce further potassium absorption. $1 \mathrm{~g}$ of Calcium Resonium can absorb about 1.3 mmol of potassium. Whole-gut lavage ${ }^{4}$ may also be helpful because slow-release tablets liberate potassium over three hours or longer, depending on the brand. ${ }^{5}$

${ }^{1}$ Beeson PB, McDermott W, Wyngaarden JB, eds. Cecil textbook of medicine, 15th ed. London: Saunders, 1979.

2 Gosselin RE, Hodge HC, Smith RP, Gleason MN. Clinical toxicology of commercial products: acute poisoning. 4th ed. Baltimore: Williams and Wilkins, 1976.

${ }^{3}$ Whang R. Hyperkalaemia: diagnosis and treatment. Am $\mathcal{f}$ Med Sci 1976;272:19-29.

4 Woo P, Hatfield A, Green JR, Hamilton SM. Whole-gut perfusion for therapeutic purgation. $\mathrm{Br} \mathrm{Med} \mathcal{F} 1976$; : :433-4.

5 Association of the British Pharmaceutical Industry. Data sheet compendium 1979-80. London: Pharmind Publications, 1979.

(Accepted 8 May 1980)

Regional Poisoning Treatment Centre, Royal Infirmary, Edinburgh EH3 9YW

R N ILLINGWORTH, BM, MRCP, medical registrar (present appointment senior registrar, accident and emergency department, General Infirmary, Leeds LS1 3EX)

A T PROUDFOOT, BSC, FRCPED, consultant physician

\section{Premedication for fibreoptic bronchoscopy: fentanyl, diazepam, and atropine compared with papaveretum and hyoscine}

Fibreoptic bronchoscopy is often conducted under local anaesthetic after premedication. The acceptability of this procedure, using papaveretum and hyoscine as premedication, has been assessed. ${ }^{1}$ Most patients tolerated the procedure well, but a significant proportion thought it unpleasant, and $45 \%$ experienced pain. We therefore compared premedication using fentanyl (a potent, short-acting opiate), diazepam, and atropine with that using papaveretum and hyoscine.

\section{Patients, methods, and results}

We assessed respiratory reserve in 57 patients requiring bronchoscopy. Five patients who had a peak flow rate $<1201 / \mathrm{min}$ were considered unfit for opiate premedication. The other 52 patients were randomly allocated for premedication by either fentanyl, diazepam, and atropine intravenously at the time of bronchoscopy, or papaveretum and hyoscine intramuscularly 45 minutes beforehand (table). Doses (depending on body weight) were fentanyl $50-150 \mu \mathrm{g}$, diazepam $5-10 \mathrm{mg}$, atropine $0.6 \mathrm{mg}$, papaveretum $10-20 \mathrm{mg}$, hyoscine $0 \cdot 2-0 \cdot 4 \mathrm{mg}$. All patients were also given lignocaine local anaesthetic spray for nose and pharynx, followed by $2 \mathrm{ml}$ of $4 \%$ lignocaine to vocal cords, and $6 \mathrm{ml}$ of $2 \%$ lignocaine to trachea and bronchial tree. Oxygen $31 / \mathrm{min}$ was administered to all patients via nasal cathete during the procedure. A questionnaire given to patients 24 hours after bronchoscopy specifically asked about their recall of the procedure and its acceptability.

Combining fentanyl, diazepam, and atropine for premedication made the procedure more acceptable. Only one recalled pain, and only two would have preferred a general anaesthetic. Complaints of sore throats were similar between groups. The bronchoscopist's identity appeared to have no effect. More patients were amnesic with fentanyl, diazepam, and atropine, but this was not statistically significant.

\section{Comment}

This single-blind trial showed that fentanyl, diazepam, and atropine appeared to be better premedication for fibreoptic bronchoscopy than papaveretum and hyoscine. A double-blind trial was impossible because one combination was given intravenously at the time of the procedure, the other intramuscularly beforehand. Nevertheless, no patient knew which drug combination he received, not did the technician who explained the questionnaire to the patient.

Of the patients who had fentanyl, diazepam, and atropine, only $8 \%$ would have preferred a general anaesthetic, whereas $58^{\circ} \%$ of those given papaveretum and hyoscine would have preferred one. Reasons for the disparity between our results with papaveretum and hyoscine and those of other workers are unclear ${ }^{1}$; in the earlier study, however, the questionnaire was given only 2-4 hours after the procedure when effects of opiate might still have been present.

We recommend that two doctors be present during the procedure in case of appreciable respiratory depression. Because respiratory depression occurs with both regimens we administered continuous oxygen, and respiratory function was tested to exclude patients in whom opiates should be avoided.

Fentanyl and papaveretum are equipotent for analgesia and respiratory depression, but the respiratory depression with fentanyl lasts 30 minutes (maximal 5 minutes), a much shorter time than with other opiates. ${ }^{2}$ A secondary peak of fentanyl occurs in the serum at 45 minutes; the clinical significance of this is uncertain, but care should be taken to give a relatively small single dose of fentanyl $(<2 \mu \mathrm{g} / \mathrm{kg}){ }^{3}$ Opiates should be avoided subsequently because "rebound" respiratory depression may occur. ${ }^{4}$ Diazepam was used as a sedative because it is shorter acting than other benzodiazepines, although it has a higher incidence of local side effects. If a large antecubital vein is used, however, the incidence of painless local venous thrombosis is reduced to around $6 \% .{ }^{\circ}$

We consider fentanyl, diazepam, and atropine safe for outpatients, provided that they are observed for six hours. The effects of fentanyl are reversible by naloxone and those of diazepam by physostigmine. ${ }^{5}$ Outpatients should be escorted home and not allowed to drive, because there is a secondary peak of diazepam in serum at $6-8$ hours due to enterohepatic recirculation. ${ }^{5}$

${ }^{1}$ Johnson NMcI, Hodson ME, Clarke SW. Acceptability of fibreoptic bronchoscopy under local anaesthesia. Practitioner 1978;221:113-4.

${ }^{2}$ Harper MH, Hickey RF, Cromwell TH, Linwood S. The magnitude and duration of respiratory depression produced by fentanyl and fentanyl plus droperidol in man. 7 Pharmacol Exp Ther 1976; 199:464-8.

${ }^{3}$ McQuay HJ, Moore RA, Paterson GMC, Adams AP. Plasma fentanyl concentrations and clinical observations during and after operation Br F Anaesth 1979;51:543-9.

${ }^{4}$ Adams AP, Pybus DA. Delayed respiratory depression after use of fentanyl during anaesthesia. $B r$ Med $\mathcal{f} 1978 ; i: 278-9$.

${ }^{5}$ Dundee JW. Benzodiazepine sedation-amnesia. Intravenous anaesthetic agents. London: Edward Arnold, 1979:67-86.

(Accepted 14 May 1980)

Anaesthetic Department, Middlesex Hospital, London W1

T GOROSZENIUK, LEK MED (WARSAW), DA, registrar

Medical Unit, Middlesex Hospital, London W1

I H NICHOLAS, $M B, M R C P$, registrar

P MARCHANT, technician

J A MCM TURNER, MB, MRCP, lecturer

N MCI JOHNSON, MD, MRCP, lecturer

Answers by 52 patients (18 men, eight women in each group) on questionnaire to discover effects of premedication given before fibreoptic bronchoscopy

\begin{tabular}{|c|c|c|c|c|c|c|c|c|c|c|c|c|}
\hline & \multirow{2}{*}{$\underset{\text { (range) }}{\text { Mean age }}$} & \multirow{2}{*}{ No recail } & \multicolumn{3}{|c|}{$\begin{array}{l}\text { Comparison with } \\
\text { expectations }\end{array}$} & \multicolumn{3}{|c|}{ Unpleasantness } & \multirow{2}{*}{ Pain } & \multirow{2}{*}{$\begin{array}{l}\text { Averse to } \\
\text { repetition }\end{array}$} & \multirow{2}{*}{$\begin{array}{c}\text { Prefer } \\
\text { general } \\
\text { anaesthetic }\end{array}$} & \multirow{2}{*}{$\begin{array}{l}\text { Sore } \\
\text { throat }\end{array}$} \\
\hline & & & $\overline{\text { Better }}$ & Same & Worse & Not & Mild & $\overline{\text { Severe }}$ & & & & \\
\hline Fentanyl, diazepam, and atropine & $\begin{array}{c}65 \\
(47-87)\end{array}$ & 10 & 12 & 3 & 1 & 4 & 11 & 1 & 1 & 4 & 2 & 12 \\
\hline Papaveretum and hyoscine & $\begin{array}{c}62 \\
(27-79)\end{array}$ & 3 & 5 & 4 & $14 * * *$ & 1 & 9 & $13 * *$ & $8^{*}$ & 10 & $15^{* * *}$ & 14 \\
\hline
\end{tabular}

Significant differences ( $\chi^{2}$ test with Yates's correction for small numbers): $*=p<0.05 ; * *=p<0.01 ; * * *=p<0.001$ 